\title{
The Mediating Effect of Psychological Capital on Authentic Leadership and Organizational Commitment among Catholic Higher Education Institutions in Batangas
}

\author{
Joseph Angelou I. Ng, Ph.D. \\ josephangelou.ng@g.batstate-u.edu.ph \\ College of Accountancy, Business, Economics and International Hospitality Management \\ Batangas State University, Rizal Ave, Extension, Batangas, 4200 Philippines
}

De La Salle Lipa, 1962 J.P. Laurel National Highway, Mataas na Lupa, Lipa City, 4217 Philippines

\begin{abstract}
Philippine higher education institutions (HEIs) constantly deal with challenges of increased employee attrition and turnover rates, more recently due to the enhanced attractiveness of free public college education in the country. More than ever, private HEIs call for administrators who exemplify a leadership style that enhances employee commitment. This study determined the mediating effect of psychological capital on the relationship between authentic leadership and organizational commitment among employees of Catholic HEIs in the Batangas province. Explanatory sequential mixed method design was utilized. Sample of the study comprised full-time academic and non-academic employees of the six Catholic HEIs in Batangas who did not hold any administrative position during the conduct of the study. The respondents accomplished a questionnaire containing standardized items for organizational commitment, authentic leadership and psychological capital. Selected respondents participated further in interviews to explore on their experiences of authentic leadership and organizational commitment.

Results revealed that employees of Catholic HEIs perceived very high levels of authentic leadership among their immediate heads and they have high levels of organizational commitment and psychological capital. Authentic leadership significantly influenced the employees' psychological capital and organizational commitment. Nevertheless, psychological capital was not found to mediate the effect of authentic leadership on organizational commitment. The insights shared by respondents during the interviews reinforced concepts of authentic leadership and organizational commitment. A Human Resource (HR) module on leadership is proposed to contribute to the business sustainability of these Catholic HEIs.
\end{abstract}

Keywords: authentic leadership; organizational commitment; psychological capital; Philippine higher education; Catholic HEIs

\section{Introduction}

Catholicism, being one of the foremost religions in the world has not only shaped faith teachings and traditions but also education. Anywhere in the world, Catholic education institutions exist to instill academic excellence coupled with Christian morals, virtues and self-discipline. They prepare students to succeed in further education, to seek holiness, and to live meaningful lives grounded on the teachings and principles of Jesus Christ (NCEA Talk, 2018). In the Philippines, although there is currently a relative balance between free education offered by public higher education institutions and private education from privately owned institutions, Philippine Catholic colleges and universities maintain strong presence. 
Just recently in March of 2018, the Commission on Higher Education realized the "education for all" principle as a thrust of globalization in education via the official release of the implementing rules and regulations (IRR) of Republic Act No. 10931. Otherwise known as the Universal Access to Quality Tertiary Education Act (UAQTEA), this law under the Duterte administration mandated free tuition and miscellaneous fees for college students enrolled in any state university or college in the country (Montemayor, 2018).

While the new law sounds promising to public HEIs, private HEIs are pushed to a disadvantaged position. The new law on free education can cause hundreds or even thousands of teachers in private colleges and universities to lose jobs as public HEIs become much more enticing for Filipino college students to enroll in (Belaro, 2017). The UAQTE can have two effects: enrolment can increase in public HEIs as compared with private HEIS and many employees of private HEIs may opt to transfer to the now better-funded public HEIs to ensure job security. Additionally, the Catholic Educational Association of the Philippines (CEAP) has confirmed the rippling negative effect of UAQTEA to both CEAP-member schools (Catholic HEIs) and the private education sector in general. From Luzon to Mindanao, Catholic HEIs have experienced decreased enrolment in school year 2018-2019 in the advent of the implementation of the free college education law; thereby compromising the future existence especially of smaller Catholic HEIs (Hernando-Malipot, 2018).

Philippine Catholic higher education institutions (HEIs) face a number of challenges in recent times. For one, they experience continuing enrolment decrease and the low commitment of teachers as evidenced by their migration to public schools. The free or low cost of public tertiary education and the increasing salaries in public colleges or universities negatively impact Catholic HEIs. Some schools lose students to public HEIs, and some teachers transfer to public institutions once their application is accepted. The sad scenario illustrates the decreased commitment of teachers to the Catholic HEI they work for, which in turn calls for more effective HEI leadership. Additionally, Catholic HEIs are expected to practice moral leadership by becoming institutions that primarily challenge the moral and social ills of the society. Hence, school leaders are expected to practice leadership that speaks of Catholic moral principles (Aguas, 2019). Lastly, Catholic schools are left with the challenge of being beacons of hope in the society; that despite adversities, they are institutions that impart such positive behaviors as hope and optimism. (Gutierrez, 2007, as cited in Gutierrez, 2012).

Just more recently, the COVID-19 pandemic has likewise brought challenges to Philippine private schools both in the basic and higher education levels. For one, the Department of Education has reported the closure of 748 private schools for SY 2020-2021, which translates to 40,345 students transferring to other private or public schools or stopping school as a result, and 3,323 teachers losing their current job and being pressured to find other means of employment (Ramos, 2020). Similarly, the Commission on Higher Education and the Philippine government have identified that there are teaching and non-teaching personnel including part-time faculty or non-permanent teaching personnel in private and public tertiary education institutions who have lost their jobs or who have not received their wages yet because of the pandemic (Commission on Higher Education, 2020).

Extraordinary and challenging times demand equally extraordinary leadership in Philippine higher education institutions to provide quality education amidst difficult times (Cuaton, 2020). Likewise, the call for commitment is heightened more than ever, so that employees can support their organization's thrust for sustainability. Hence, this study delved deeper into authentic leadership and organizational commitment among Catholic higher education institutions. The dearth of studies on the positive effect of authentic leadership to the organizational commitment of employees in an academic environment (Roncesvalles \& Gaerlan, 2020) prompted the researcher to conduct this study.

A number of previous studies proved the interaction among authentic leadership, organizational commitment and psychological capital. First, a study explored on the mediating role of positive psychological capital in the relationship between authentic leadership and organizational commitment among employees working both in the private and public sectors. The results demonstrated psychological capital to have a 
mediating effect on the relationship between authentic leadership and organization commitment in three out of four dimensions of psychological capital (self-efficacy, hope and optimism). Authentic leadership has positive influence on both organizational commitment and psychological capital. Similarly, psychological capital positively influences organizational commitment (Rego, Lopes \& Nascimento, 2016).

Next, the mediating role of positive psychological capital on the relationship between authentic leadership and organizational commitment was measured among academic and administrative employees of Al-Azhar University - Gaza in Israel. Using quantitative data gathered from the respondents on the three aforementioned variables, the researchers revealed that the authentic leadership of the school administrators has a positive influence on both organizational commitment and positive psychological capital. Nonetheless, psychological capital insignificantly mediated the relationship between authentic leadership and organizational commitment (Albashiti, Hajjaj \& Thabet, 2017).

Third, a study explored on the effects of authentic leadership and organizational commitment on the turnover intention of American employees working in the hospitality industry. The authors aimed to determine whether the four distinctive components of authentic leadership (self-awareness, relational transparency, balanced processing and internalized moral perspective) influence the employees' organizational commitment; and whether organizational commitment mediates the relationship between authentic leadership and turnover intention. Through structural equation modeling, results revealed a positive influence of hospitality managers' authentic leadership on the organizational commitment of the employees. Likewise, organizational commitment has been found to mediate the inverse relationship between authentic leadership and turnover intention (high leadership reduces turnover intention) (Gatling, Kang \& Kim, 2016).

Similarly, a research investigated the impact of authentic leadership on employee performance, taking organizational commitment as a mediating variable. Data for the study were acquired from employees of various tourism agencies in the Guilan province of Iran. Findings showed that the perceptions of their leaders or managers' authentic leadership positively affect both employee performance and organizational commitment. There is likewise a significant relationship between authentic leadership and employee performance, which is positively mediated by organizational commitment (Hadian Nasab \& Afshari, 2019).

A similar study was conducted on the influence of authentic leadership on employee organization commitment in a state hospital in South Africa. With 222 employees accomplishing the survey questionnaire containing items on authentic leadership and organizational commitment; data have been analyzed using regression analyses. Findings demonstrated that the hospital leaders' authentic leadership scores predicted that of employees' organizational commitment scores. More specifically, it has been found out that authentic leadership influenced the continuance and normative commitment of the respondents. The authors reiterated that leaders of organizations who practice authentic leadership may have the capacity to retain employees by enhancing their commitment to the organization (Hlongwane \& Olivier, 2017).

In the Philippines, there are likewise previous studies that have investigated the relationship between authentic leadership and organizational commitment. For one, a study examined the relationship between authentic leadership and authentic followership, and their effects to self-efficacy, work engagement and organizational commitment. This descriptive-correlational research was conducted among nursing administrators and staff in various health institutions in the province of Tarlac. Findings of the study revealed a significant relationship between authentic leadership and authentic followership, and both variables are significant predictors of self-efficacy, work engagement and organizational commitment. Promotion of authentic leadership was recommended, and the study yielded a model for leadership and staff development initiatives (Sunga, 2020).

Another local study on authentic leadership and organizational commitment was completed. They conducted this study on the notion that at present, there are only few studies that have focused on the positive impact of authentic leadership in academic institutions. Specifically, the researchers examined the effects of 
authentic leadership of the deans on teacher morale and organizational commitment in higher education institutions. The study used the quantitative approach and included faculty members in both public and private higher education institutions in Manila. The findings confirmed that authentic leadership positively influences the morale and organizational commitment of the teachers in higher education. Also, teacher morale positively affects their organizational commitment (Roncesvalles \& Gaerlan, 2020).

This study is primarily anchored on the model of authentic leadership that has been proposed by Walumbwa and colleagues. Authentic leadership is specifically defined as "a pattern of leader behavior that draws upon and promotes both positive psychological capacities and a positive ethical climate, to foster greater self-awareness, an internalized moral perspective, balanced processing of information, and relational transparency on the part of leaders working with followers, fostering positive self-development" (Walumbwa, Avolio, Gardner, Wernsing \& Peterson, 2008).

The four components of authentic leadership are self-awareness, internalized moral perspective, balanced processing and relational transparency. First, relational transparency is the open and honest presentation of oneself to others. Next, internalized moral perspective is an individual's use of his internal moral standards and values to guide his behaviour. He does not allow outside or societal pressures to control them. Third, balanced processing refers to the objective processing of information and others' opinions in relation to decision-making. Lastly, self-awareness refers to a leader's personal insights. It relates to the continuous process by which individuals understand themselves, discover their strengths and weaknesses, and assess the impact they have on others (Northhouse, 2012).

The theory of organizational commitment was used in this study. In discussing organizational commitment, the multidimensional model by Meyer and Allen in 1991 which comprises three commitment components (affective, normative and continuance) remains most significant as it enjoys greater consensus, acceptance and use (Rego, Lopes \& Nascimento, 2016). The authors basically defined organizational commitment as "a psychological state that characterizes the employee's relationship with the organization, and has implications for the decision to continue or discontinue membership in the organization” (Meyer \& Allen, 1991).

The first dimension of organizational commitment is affective commitment, which relates to an individual's attachment to the organization in emotional terms. It can originate from the treatment and respect he receives as a member of the organization, and the trust and confidence he attributes to his superiors. Next, continuance commitment refers to an individual's intention to stay in the organization by virtue of the rewards he gets for staying and the possible costs should he decide to leave. Lastly, normative commitment is one's feeling of the moral obligation or duty to stay with the organization (Wong \& Tong, 2013).

Lastly, this study utilized the theory of psychological capital which has been proposed by Luthans, Youssef and Avolio in a book they have written of the same title. Psychological capital, or PsyCap, was defined as: "an individual's positive psychological state of development characterized by: (1) having confidence (selfefficacy) to take on and put in the necessary effort to succeed at challenging tasks; (2) making a positive attribution (optimism) about succeeding now and in the future; (3) persevering toward goals and, when necessary, redirecting paths to goals (hope) in order to succeed; and (4) when beset by problems, sustaining and bouncing back and even beyond (resilience) to attain success" (Luthans, Youssef \& Avolio, 2007).

\section{Objectives}

The aim of the study is to determine the mediating role of psychological capital in the relationship between authentic leadership and organizational commitment among employees of Catholic Higher Education Institutions (HEIs) in the Batangas province. Specifically, it sought to answer the following questions:

1. How may the level of organizational commitment be described among the employees of the Catholic HEIs? 
2. How do the respondents perceive the level of authentic leadership among their immediate school leaders?

3. What is the level of psychological capital among the respondents in terms of:

3.1. efficacy;

3.2. hope;

3.3. resilience; and

3.4. optimism?

4. Does the perceived level of authentic leadership affect the organizational commitment of the respondents?

5. Does psychological capital mediate the effect of authentic leadership to the organizational commitment of the respondents?

6. How do the respondents perceive the importance of leadership and organizational commitment based on their experiences in working for a Catholic HEI?

7. Based on the results, what human resource module on leadership for business sustainability can be developed?

\section{Methodology}

Following were the methods and techniques which were utilized by the researcher in the study:

\subsection{Research Design}

The research design used in the current undertaking is mixed methods research, defined as an approach that entails the collection and analyses of both quantitative and qualitative data within one study (Shorten \& Smith, 2017). Out of the four common types of this research design, the study more specifically employed the explanatory sequential mixed method design. It is characterized first by the conduct of quantitative research in terms of data acquisition and analyses followed by qualitative research to explore more on the results generated (Creswell, 2014).

\subsection{Respondents of the Study}

The respondents of this study were 146 male and female full-time college employees from the Catholic higher education institutions in the province of Batangas in the Philippines. The six Catholic HEIs which participated in this study are as follows: De La Salle Lipa; Immaculate Conception College - Balayan; La Consolacion College - Tanauan; St. Bridget College - Batangas City; Saint Joseph College - Rosario; and Sta. Teresa College.

The target employees assumed such positions as academic teaching personnel, academic support personnel or non-academic personnel, provided that they do not hold any administrative or supervisory positions in the organization at the time this study was conducted.

Primarily, Slovin's Formula was used to obtain the sample size (n) from the total population of the employees. Then, to acquire the sample size of respondents in each school and to ensure that each school was well represented, stratified random sampling using proportional allocation based on the number of respondents per school was utilized. 


\subsection{Data Gathering Instrument}

The data gathering instrument used in this study is a survey questionnaire intended to measure organizational commitment, authentic leadership and psychological capital.

For organizational commitment, the commitment scale by Meyer, Allen and Smith (1993) was utilized, and it is the revised version of the original construct by Allen and Meyer (1990). It consists of a total of 18 items, with six items each for the three components of organizational commitment: affective commitment, continuance commitment and normative commitment. They are rated on a seven-point scale, ranging from strongly agree (7) to strongly disagree (1). Items are stated both positively and negatively. Scoring is reversed for the negatively stated items.

For the respondents' perceived level of authentic leadership, the Authentic Leadership Questionnaire (ALQ - Rater version) by Avolio, Gardner and Walumbwa (2007) was used. It consists of 16 items which represent the four dimensions of authentic leadership: self-awareness, internalized moral perspective, balanced processing and relational transparency. Items are stated in the third-person perspective and are positive. Items can be answered through a Likert scale which ranges from frequently if not always (5) to never (1).

Lastly, the PsyCap-24 Questionnaire (self-rater version) devised by Luthans, Avolio and Avey (2007) was used to measure psychological capital. It comprises 24 items to measure psychological capital in terms of efficacy, hope, resilience and optimism. Items are stated positively and in the first-person perspective. Responses range from a 6-point Likert scale (strongly agree to strongly disagree). Scoring is reversed for items 13, 20 and 23.

Since all three questionnaires are standardized, respective permission to use each one was obtained by the researcher. First, for organizational commitment, an academic license was applied for and attained at no cost, because this undertaking is academic, a single project and of non-commercial intention. The researcher applied for the academic license through the website created by the University of Western Ontario, which was solely dedicated for researchers to gain permission in using the employee commitment scales. As for authentic leadership and psychological capital, research permissions were both obtained online via Mind Garden. Similarly, because of the nature of the present study, research permissions for ALQ and the PsyCap-24 questionnaires were obtained for free. The researcher submitted the current abstract for this study, which underwent evaluation and consequent approval. Additionally, an approval for remote online use for both ALQ and PsyCap-24 has been acquired from Mind Garden.

\subsection{Data Gathering Procedure}

Prior to the start of the quantitative data gathering phase, the researcher coordinated with the Pastoral Affairs Research Office of the Lipa Archdiocese (PAROLA), a key office under the Archbishop, which handles research-related activities in the Archdiocese. This led to a consequent endorsement of the researcher by the PAROLA Director to LIDICSA to obtain approval and official endorsement in gathering data from the six Catholic HEIs in the Batangas province. Once coordination and endorsements were achieved, the researcher personally communicated with the employees in the schools through their respective human resource departments, research offices or administrative assistants. Each Catholic HEI was provided with an option on their preferred data gathering method either by the provision of a printed survey questionnaire or by the use of a Google Form online survey. Attached to each questionnaire was an informed consent form stating the purpose of the research study, a short description of the questionnaire, the approximate time of questionnaire completion and their rights for confidentiality and withdrawal as participants.

After quantitative results have been analyzed, one-on-one semi-structured interviews were scheduled online to explore more on the experiences of authentic leadership and organizational commitment among 
selected employees. Out of the 146 employees who participated in the survey, eight of them were randomly selected to participate in the interviews. The guide questions posed to the interviewees during the session are presented in the joint display table later in the discussion.

Computerized transcriptions of the participants' responses were then furnished in MS Excel format. Data were analyzed using a separate software (IBM SPSS Text Analytics Software) available through the Office of Research and Publications of De La Salle Lipa after approval from the office was obtained.

\subsection{Statistical Treatment of Data}

The Statistical Package for Social Sciences (SPSS) were used in the analyses of numerical data. Frequency and percentage, weighted mean, linear regression, and Baron and Kenny mediation analysis were the tools used to interpret and analyze the numerical data.

\section{Results and Discussion}

The responses of the Catholic HEI employees to each item of the questionnaire and to the interview questions were tallied, compared and interpreted. This section presents the results on organizational commitment, authentic leadership and psychological capital.

Table 1. Overall Assessment on Organizational Commitment

\begin{tabular}{cccc}
\hline Organizational Commitment & Mean & Standard Deviation & Interpretation \\
\hline Affective Commitment & 5.69 & 1.04 & High Commitment \\
Continuance Commitment & 4.46 & 1.74 & Moderate Commitment \\
Normative Commitment & 5.27 & 1.05 & High Commitment \\
\hline Overall Mean & 5.14 & 1.41 & High Commitment \\
\hline
\end{tabular}

Table 1 shows that the respondents have a high commitment to the respective Catholic HEIs they work for as evidenced by an overall mean score of 5.14 and a standard deviation value of 1.41. Of the three dimensions of organizational commitment, affective commitment attained the relatively highest mean score of 5.69; followed by normative commitment with a mean score of 5.27. Both mean scores are interpreted as high. Score was relatively lowest for continuance commitment at 4.46 which, although interpreted at a moderate level, is still considered positive. The data imply that the employees have high and positive levels of commitment to their current work in the different Catholic HEIs in the province of Batangas. They express the willingness to stay committed to the organization because of a number of reasons. For one, they are happy at work because they feel that they are valued and the principles they uphold coincide with those that the organization advocates. Likewise, they have high commitment because they feel they have a moral obligation to their students and their parents, their co-employees and administrators, and other stakeholders. Lastly, the employees stay because they find their work important in the possible absence of an alternative work option. These results are comparable with the previous study among teachers of selected Catholic HEIs in the Philippines which yielded high levels of commitment in the three dimensions using the same ranges of interpretation: high affective commitment (5.42), high continuance commitment (4.66) and high normative commitment (5.45) (Batugal \& Tindowen, 2019). The commitment of the employees in Catholic HEIs is based more on their voluntary willingness, emotional attachment and moral obligations than on the rewards they get from them. While material benefits of employment are still recognized as important aspects of commitment, they did not surpass the reasons pertaining to the genuine willingness of the employees to stay and to work for the organization. After all, affective commitment is the most important dimension of organizational commitment (Zeidan, 2006, as cited in Akar, 2018). 
Table 2. Overall Assessment on Authentic Leadership

\begin{tabular}{cccc}
\hline Authentic Leadership & Mean & Standard Deviation & Interpretation \\
\hline Relational Transparency & 4.05 & 0.96 & Very High \\
Internalized Moral Perspective & 4.13 & 0.87 & Very High \\
Balanced Processing & 4.18 & 0.92 & Very High \\
Self-Awareness & 4.09 & 0.88 & Very High \\
\hline Overall Mean & 4.10 & 0.92 & Very High \\
\hline
\end{tabular}

As can be gleaned in table 2, the employees of Catholic HEIs perceive their immediate leaders to have a very high level of authentic leadership through an overall mean score of 4.10 and a standard deviation value of 0.92. In terms of the four dimensions, assessment yielded the highest mean score on balanced processing at 4.18 with a standard deviation of 0.92 ; followed by internal moral perspective at 4.13 and a standard deviation of 0.87 ; self-awareness at 4.09 and a standard deviation of 0.88 ; and lastly, relational transparency at 4.05 and a standard deviation of 0.96 . All of the scores of these dimensions fall on very high. Results concur with a previous finding on the levels of authentic leadership among teachers of a higher education institution in the Philippines. The said study found high levels of relational transparency, internalized moral perspective, balanced processing and self-awareness among the respondents. Equally a high overall assessment of authentic leadership was noted among the respondents (Arceño, Ag \& Adamu, 2019).

Table 3. Overall Assessment on Psychological Capital

\begin{tabular}{cccc}
\hline Psychological Capital & Mean & Standard Deviation & Interpretation \\
\hline Efficacy & 5.00 & 0.80 & High \\
Hope & 4.93 & 0.85 & High \\
Resilience & 4.83 & 0.81 & High \\
Optimism & 4.42 & 0.99 & High \\
\hline Overall Mean & 4.79 & 0.51 & High \\
\hline
\end{tabular}

As shown in table 3, the overall mean of the employees' level of psychological capital is 4.79 with a standard deviation value of 0.51 , which is interpreted as high. In terms of its four sub-variables, all mean scores are equally high, and the values are already arranged as to how they are presented in the table. The highest average is noted on efficacy (5.00); followed by hope at 4.93; then resilience at 4.83; and lastly, optimism at 4.42. The overall result is comparable with a previous study where majority of the respondents who are members of the Philippine National Police have a high level of psychological capital Arcega \& Caballero, 2019). It is also comparable with the finding of a study where a high level of psychological capital was noted from the employees of a higher education institution in Israel (Albashiti, Hajjaj \& Thabet, 2017) .

The results demonstrate that the respondents have high psychological capital. This is favorable, as it has been defined to be the composite of all positive behaviors that an individual possesses and exhibits (Erkus \& Findikli, 2013). Hiring employees with high levels of psychological capital is beneficial for any organization, including Catholic HEIs. The organization can take the opportunity to utilize these personal traits of their employees in further attaining its goals and objectives. This is why psychological capital is considered an internal business resource (Biricik, 2020). The dimensions of efficacy, hope, resilience and optimism are parallel with Christian values that Catholic HEIs uphold; hence, these dimensions of psychological capital can be considered useful in reinforcing the vision, mission, goals and objectives of the organization. They provide employees with a perspective focused on success especially at work (Peterson, et al., 2011). 
Table 4. Effect of Authentic Leadership on Organizational Commitment

\begin{tabular}{ccccccc}
\hline Variable & $\mathrm{B}$ & Std. Error & $\mathrm{t}$-value & $\mathrm{p}$-value & Decision & Interpretation \\
\hline Constant & 4.350 & 0.282 & 15.43 & 0.000 & ${\text { Reject } \mathrm{Ho}_{1}}$ & Significant \\
Authentic Leadership & 0.192 & 0.068 & 2.842 & 0.005 & ${\text { Reject } \mathrm{Ho}_{1}}$ & Significant \\
\hline Model Summary: $\mathrm{R}=0.230 ; \mathrm{R}^{2}=0.053$ & & & & & \\
Regression Model: $\mathrm{F}=8.079 ; \mathrm{p}=0.005$ & & & & &
\end{tabular}

As can be gleaned from the table, $5.30 \%$ of the variability in organizational commitment can be attributed to authentic leadership as noted from the R2 value. The effect of authentic leadership to organizational commitment is significant as p-value is less than 0.05 ; hence, the null hypothesis is rejected. The beta coefficient of 0.192 denotes a positive effect of authentic leadership to organizational commitment.

The results demonstrate that authentic leadership has a positive and significant effect on organizational commitment. The high authentic leadership perceived by the Catholic HEI employees among their immediate heads influences their equally high commitment to the organization. The respondents see their bosses leading with transparency, with high moral values that translate into their actions and decisions, with fairness in treating their subordinates, and with a clear sense of their own strengths and weaknesses, which affect their intention to remain committed to the organization. The results coincide with a number of studies previously discussed, which established the positive effect of authentic leadership to organizational commitment (Roncesvalles \& Gaerlan, 2020; Rego, Lopes \& Nascimento, 2016; Albashiti, Hajjaj \& Thabet, 2017; Gatling, Kang \& Kim, 2016; Hadian Nasab \& Afshari, 2019; Hlongwane \& Olivier, 2017; Sunga, 2020).

The table also reflected a significant effect of a constant variable on organizational commitment as evidence by a p-value 0.000 . Besides authentic leadership, there are other important factors that predict the commitment of the Catholic HEI employees. Take for one the work engagement of call center employees which has been found to have an effect on organizational commitment (Simons \& Buitendach, 2013).

Table 5. Parallel Mediation Analysis of Psychological Capital in the Effect of Authentic Leadership to Organizational Commitment

Model 1:

\begin{tabular}{ccccccc} 
Variable & B & $\begin{array}{c}\text { Std. } \\
\text { Error }\end{array}$ & $\begin{array}{c}\mathrm{t}- \\
\text { value }\end{array}$ & $\begin{array}{c}\text { p- } \\
\text { value }\end{array}$ & $\begin{array}{c}\text { Deci- } \\
\text { sion }\end{array}$ & Int. \\
\hline Constant & 4.350 & 0.282 & 15.425 & 0.000 & $\begin{array}{c}\text { Reject } \\
\text { Ho }\end{array}$ & Sig. \\
$\begin{array}{c}\text { Authentic } \\
\text { Leadership }\end{array}$ & 0.192 & 0.068 & 2.842 & 0.005 & $\begin{array}{c}\text { Reject } \\
\mathrm{Ho}_{1}\end{array}$ & Sig. \\
\hline
\end{tabular}

Dependent Variable: Organizational Commitment

\begin{tabular}{|c|c|c|c|c|c|c|}
\hline Variable & B & $\begin{array}{l}\text { Std. } \\
\text { Error }\end{array}$ & $\begin{array}{c}\mathrm{t}- \\
\text { value }\end{array}$ & $\begin{array}{c}\mathrm{p}- \\
\text { value }\end{array}$ & $\begin{array}{l}\text { Deci- } \\
\text { sion }\end{array}$ & Int. \\
\hline Constant & 4.041 & 0.298 & 13.570 & 0.000 & $\begin{array}{c}\text { Reject } \\
\mathrm{Ho}_{2}\end{array}$ & Sig. \\
\hline $\begin{array}{l}\text { Authentic } \\
\text { Leadership }\end{array}$ & 0.233 & 0.071 & 3.259 & 0.001 & $\begin{array}{c}\text { Reject } \\
\mathrm{Ho}_{2}\end{array}$ & Sig. \\
\hline
\end{tabular}

Dependent Variable: Psychological Capital (Efficacy)

\begin{tabular}{|c|c|c|c|c|c|c|}
\hline Variable & B & $\begin{array}{l}\text { Std. } \\
\text { Error }\end{array}$ & $\begin{array}{c}\mathrm{t}- \\
\text { value }\end{array}$ & $\begin{array}{c}\text { p- } \\
\text { value }\end{array}$ & $\begin{array}{l}\text { Deci- } \\
\text { sion }\end{array}$ & Int. \\
\hline Constant & 4.268 & 0.304 & 14.050 & 0.000 & $\begin{array}{c}\text { Reject } \\
\mathrm{Ho}_{3}\end{array}$ & Sig. \\
\hline $\begin{array}{l}\text { Authentic } \\
\text { Leadership }\end{array}$ & 0.161 & 0.073 & 2.209 & 0.029 & $\begin{array}{c}\text { Reject } \\
\mathrm{Ho}_{3}\end{array}$ & Sig. \\
\hline
\end{tabular}

Dependent Variable: Psychological Capital (Hope)
Model 4:

\begin{tabular}{ccccccc}
\hline Variable & B & $\begin{array}{c}\text { Std. } \\
\text { Error }\end{array}$ & $\begin{array}{c}\text { t- } \\
\text { value }\end{array}$ & $\begin{array}{c}\text { p- } \\
\text { value }\end{array}$ & $\begin{array}{c}\text { Deci- } \\
\text { sion }\end{array}$ & Int. \\
\hline Constant & 4.213 & 0.274 & 15.393 & 0.000 & $\begin{array}{c}\text { Reject } \\
\mathrm{Ho}_{4}\end{array}$ & Sig. \\
$\begin{array}{c}\text { Authentic } \\
\text { Leadership }\end{array}$ & 0.150 & 0.066 & 2.284 & 0.024 & $\begin{array}{c}\mathrm{Reject}^{\mathrm{Ho}} \\
\mathrm{Ho}_{4}\end{array}$ & Sig.
\end{tabular}

Dependent Variable: Psychological Capital (Resilience)

\begin{tabular}{|c|c|c|c|c|c|c|}
\hline Variable & B & $\begin{array}{c}\text { Std. } \\
\text { Error }\end{array}$ & $\begin{array}{c}\mathrm{t}- \\
\text { value }\end{array}$ & $\begin{array}{c}\mathrm{p}- \\
\text { value }\end{array}$ & $\begin{array}{l}\text { Deci- } \\
\text { sion }\end{array}$ & Int. \\
\hline Constant & 3.857 & 0.227 & 17.006 & 0.000 & $\begin{array}{c}\text { Reject } \\
\mathrm{Ho}_{5}\end{array}$ & Sig \\
\hline $\begin{array}{l}\text { Authentic } \\
\text { Leadership }\end{array}$ & 0.136 & 0.054 & 2.510 & 0.013 & $\begin{array}{c}\text { Reject } \\
\mathrm{Ho}_{5}\end{array}$ & Sig \\
\hline
\end{tabular}

Dependent Variable: Psychological Capital (Optimism) 


\begin{tabular}{|c|c|c|c|c|c|c|c|}
\hline Variable & $\mathrm{B}$ & Std. Error & t-value & p-value & Decision & Interpretation & Indirect Effect \\
\hline Constant & 3.141 & 0.517 & 6.072 & 0.000 & & & \\
\hline Authentic Leadership & 0.133 & 0.068 & 1.958 & 0.052 & Accept $\mathrm{Ho}_{6}$ & Not Sig. & \\
\hline Efficacy & 0.154 & 0.101 & 1.537 & 0.127 & Accept $\mathrm{Ho}_{6}$ & Not Sig. & 0.036 \\
\hline Hope & 0.203 & 0.117 & 1.732 & 0.086 & Accept $\mathrm{Ho}_{6}$ & Not Sig. & 0.033 \\
\hline Resilience & -0.05 & 0.126 & -0.42 & 0.676 & Accept $\mathrm{Ho}_{6}$ & Not Sig. & -0.008 \\
\hline Optimism & -0.02 & 0.121 & -0.12 & 0.903 & Accept $\mathrm{Ho}_{6}$ & Not Sig. & -0.002 \\
\hline
\end{tabular}

The process of parallel mediation analysis using a series of regression analyses is presented in table 5, and is described in a six-step model.

As can be gleaned from the table, models 1 to 5 refer to the regression analyses made to determine the effect of authentic leadership (independent variable) to organizational commitment and to psychological capital, the dependent and mediating variables, respectively. All models demonstrate the significant effect of authentic leadership on organizational commitment and on the four dimensions of psychological capital (efficacy, hope, resilience and optimism) as evidenced by the p-values which are less than 0.05 . These results allowed for mediation analysis to take place.

Model 6 presents the parallel mediation that took place when the four mediating variables (efficacy, hope, resilience and optimism) were added to the model of authentic leadership predicting organizational commitment. Using multiple regression analysis, it can be noted that not one among the four dimensions of psychological capital significantly predicts organizational commitment, as all their $\mathrm{p}$-values are greater than 0.05. As no dimension was noted to be a significant predictor of organizational commitment, the conduct of the Sobel test -a tool used to identify if a variable is a significant mediator, or otherwise - was no longer carried out.

The model likewise presents that the indirect path of authentic leadership to organizational commitment as simultaneously mediated by the four dimensions of psychological capital is not significant. Results yielded a 0.059 total indirect effect of authentic leadership to organizational commitment through efficacy, hope, resilience and optimism with a $30.7 \%$ mediation effect. The effect of authentic leadership on organizational commitment via the multiple regression analysis is not significant, as evidenced by the p-value of 0.052 . This consequently implies that no mediation by psychological capital occurred.

The results demonstrate that psychological capital does not mediate the effect of authentic leadership to organizational commitment. It means that the Catholic HEI employees' level of psychological capital does not explain the significant link between their perception of authentic leadership and their own level of organizational commitment. While each yielded significant influences when paired with another, the interaction made among all three did not cause psychological capital to explain the relationship between authentic leadership and organizational commitment. The result is parallel with a previous finding that psychological capital does not mediate the relationship between authentic leadership and organizational commitment among employees of a higher education institution (Albashiti, Hajjaj \& Thabet, 2017).

Table 6. Joint Display Table to Integrate the Quantitative and Qualitative Results

\begin{tabular}{|c|c|c|}
\hline Quantitative Results & Qualitative Follow-Up Themes & Interpretation (Meta-Inference) \\
\hline $\begin{array}{l}\text { Organizational Commitment } \\
\qquad(\mu=5.14) \\
\text { High Commitment }\end{array}$ & $\begin{array}{c}\text { In your experience, why is staying committed to } \\
\text { the Catholic HEI you work for important? } \\
\text { GRATITUDE } \\
\text { work, congruence of values, responsibility }\end{array}$ & $\begin{array}{l}\text { The employees see the value of } \\
\text { belonging to an organization as a way to } \\
\text { sustain their needs and those of their } \\
\text { families. }\end{array}$ \\
\hline $\begin{array}{l}\text { Relational Transparency } \\
\text { \#3: encourages everyone to } \\
\text { speak their mind } \\
(\mu=4.27)\end{array}$ & $\begin{array}{c}\text { How does open communication become } \\
\text { important in a leader-follower relationship? } \\
\text { PARTNERSHIP } \\
\text { collaboration, empowerment }\end{array}$ & $\begin{array}{l}\text { Open communication does not only foster } \\
\text { a stronger relationship between leaders and } \\
\text { followers. It also facilitates partnership and } \\
\text { employee empowerment. }\end{array}$ \\
\hline
\end{tabular}


Authentic Leadership $(\mu=4.10)$ Very High

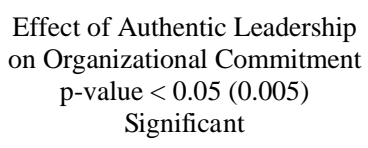

What qualities are most important that leaders of an organization should possess? Why? TRANSFORMATION setting good examples, maintaining commitment

How does the leadership of your immediate head affect your commitment as an employee of the Catholic HEI you work for? CARE AND CONCERN commitment, empowerment, heart

Do you agree that one's skills and capacities are likewise important factors in determining one's commitment in the organization? Why, or why not?

SELF-WORTH fulfillment, recognition
While leadership influences commitment, employees likewise perceive the commitment that their leaders project to have an effect on their intention to remain in the organization.

Great leaders of organizations do not only possess the intellect and the will to act; they also have the care and concern for their followers.

Leadership is a holistic function in the organization. It requires the collective use of one's head, hands and hearts.

Organizations must ensure that employees are duly recognized and appreciated for the contributions that they make to attain its goals and objectives.

Feelings of self-worth reinforce commitment.

As can be gleaned from the table, results are in three major columns. The first column presents the five highlight results from the statistical analyses of quantitative data which have been the bases for the five interview questions as follow-up on the participants' numerical responses. On the second column, the questions are presented along with their respective 'super themes' - themes constructed to represent the subsequent themes or categories suggested by the IBM SPSS Text Analytics software. By comparing and integrating the quantitative and qualitative data results, some findings have been affirmed and others have been reinforced with additional concepts through meta-inferences that are presented on the third column.

\section{Proposed HR Module on Leadership}

The output of this study is a proposed module on leadership. It is intended to enhance the leadership skills of the participants (which include Catholic HEI administrators and key employees), and to motivate them to contribute to the aim of their organization to maintain business sustainability.

Entitled "ParabLEAD," the proposed module was constructed with careful consideration of the nature of the organizations they are intended for. Staying true to Catholic teachings and traditions, ParabLEAD discusses various concepts of leadership related to selected parables of Jesus Christ in the New Testament of the Bible - hence, the name, which is the shortened form for "Parables on Leadership."

The ParabLEAD module consists of 27 pages and comprises contents usually found in an HR module: title; objectives; schedule or allotted time; target participants; prerequisite module/s; target venue; materials and equipment needed; list of topics or contents; a brief introduction; comprehensive discussions of the topics; conclusion; a list of references used; and a sample evaluation tool for the participants. The five topics focusing on the parables and the dimensions of leadership have been presented in an orderly manner via the four-letter acronym "P-R-A-Y (Parable, Reflection, Application, Your Turn)." Each topic begins with the presentation of the parable followed by a reflection of the lessons that can be obtained from it. Third, an application of the parable lessons on the highlighted leadership dimension is made, usually focusing on tips for better leadership. It concludes with a simple writing and reflection activity based on the leadership dimension in focus - hence the title Your Turn. 


\section{Conclusions}

The employees of Catholic HEIs in the Batangas province have a high level of commitment to the organizations they work for. They perceive a very high level of authentic leadership among their immediate heads. They have an equally high level of psychological capital in all four dimensions: efficacy, hope, resilience and optimism.

The authentic leadership of the Catholic HEI administrators has a positive and significant effect on the organizational commitment of their academic and non-academic employees. Conversely, psychological capital does not mediate the effect of authentic leadership on organizational commitment. The respondents perceive the importance of authentic leadership and organizational commitment in Catholic higher education institutions. The HR module on leadership is a useful tool in enhancing the Christian leadership traits of the school administrators, and in motivating them to contribute to the business sustainability of their organizations.

\section{Recommendations}

Based on the aforementioned results, this study recommends that higher education institutions plan for and implement employee development programs that will serve to maintain or even enhance their leadership skills, commitment and overall positive behaviors at work and in life. Similarly, it recommends that the Catholic HEIs promote the practice of authentic leadership among their school heads by promoting activities grounded on Catholic teachings and values that focus on their self-awareness, relational skills, moral principles and decision-making skills. Third, it suggests that higher education institutions provide more opportunities for their employees to be sent to relevant training programs. Through their respective human resource departments, the implementation of periodic recognition activities for their employees is likewise proposed.

As regards the conduct of future studies, this study recommends the conduct of researches to assess the effects of other relevant variables on the commitment of employees to their organizations. It also suggests the conduct of similar studies to Catholic basic education institutions and other private and public schools and even to other types of organizations, such as the healthcare and manufacturing industries. Lastly, it recommends that future researches identify what other variables can possibly mediate the effect of authentic leadership to organizational commitment.

\section{Acknowledgements}

The researcher extends his gratitude to God, first and foremost; to his family, relatives and friends; to Dr. Elisa Diaz, his adviser; to Dr. Bendalyn Landicho, Dr. Rica Ani, Dr. Realiza Mame, Dr. Gina Bonifacio and Ms. Janet Manalo, his panel members; to Dr. Robert Marcelo, the statistician; to Dr. Jose Macatangay, the grammarian; to the administrators of the Catholic HEIs; and to the 146 employees of the Catholic HEIs who served as respondents of this study. Without their valuable contributions in different magnitude and forms, this study will not have come to its fruition in the first place. 


\section{References}

Aguas J.J.S. (2019) Catholic Education in the Philippines. In: Peters M. (eds) Encyclopedia of Teacher Education. Springer, Singapore. https://doi.org/10.1007/978-981-13-1179-6_147-1

Akar, H. (2018). The Relationships between Quality of Work Life, School Alienation, Burnout, Affective Commitment and Organizational Citizenship: A Study on Teachers. European Journal of Educational Research, 169-180.

Albashiti, B., Hajjaj, K., \& Thabet, W. (2017). Authentic Leadership and Organizational Commitment: The Mediating Role of Positive Psychological Capital Case of Alazhar University-Gaza. OSR Journal of Business and Management (IOSR-JBM), 19(10), 1-8.

Allen, N., \& Meyer, J. (1990). The measurement and antecedents of affective, continuance and normative commitment to the organization. Journal of Organizational Behavior, 705-711.

Arcega, A.M. \& Caballero, R.T. (2019). The Moderating Effects of Psychological Capital on Workplace Bullying and Burnout in the Philippine National Police. International Journal of Advanced Research and Publications, 3(5), 128-137.

Arceño, R.A., Ag, S.I., \& Adamu, T.I. (2019). Assessment on Dimensions of Authentic Leadership of College Teachers. PEOPLE: International Journal of Social Sciences, 5(1), 205-216.

Avolio, B. J., Gardner, W. L., \& Walumbwa, F. O. (2007). Authentic Leadership Questionnaire. [Measurement Instrument]. Retrieved November 8, 2020, from Mind Garden, Inc. www.mindgarden.com

Batugal, M.L., \& Tindowen, D.J. (2019). Influence of Organizational Culture on Teachers' Organizational Commitment and Job Satisfaction: The Case of Catholic Higher Education Institutions in the Philippines. Universal Journal of Educational Research, 7(11), 2432-2443.

Belaro, S.B. (2017, August 9). Disadvantages of free college education law. Press Reader. Retrieved January 30, 2021, from https://www.pressreader.com/philippines/sunstar-davao/20170809/281741269514801

Biricik, Y. S. (2020). The Relationship between Psychological Capital, Job Performance and Job Satisfaction in Higher Education Institutions Offering Sports Education. World Journal of Education, 10(3), 57-64.

Commission on Higher Education. (2020, August 22). CHED heeds the call of displaced teachers; lauds lawmakers for granting proposal of one-time cash aid to faculty members. Retrieved November 24, 2020, from https://ched.gov.ph/ched-heeds-thecall-of-displaced-teachers-lauds-lawmakers-for-granting-proposal-of-one-time-cash-aid-to-faculty-members/

Creswell, J. W. (2014). Research Design: Qualitative, Quantitative and Mixed Methods Approaches. 4th ed. Los Angeles: Sage Publications, Inc.

Cuaton, G. (2020). Philippine Higher Education Institutions in the Time of COVID-19 Pandemic. Revista Românească pentru Educaţie Multidimensională, 12, 61-70.

Erkus, A., \& Findıklı, M. A. (2013). A study on the effect of psychological capital on job satisfaction, job performance and intention to quit. Journal of Istanbul University Faculty of Business Administration, 42(2), 302-318.

Gatling, A., Kang, H.J.A. and Kim, J.S. (2016), The effects of authentic leadership and organizational commitment on turnover intention. Leadership \& Organization Development Journal, 37(2), 181-199.

Gutiérrez, A.L.V. (2007). Catholic Schools in the Philippines: Beacons of Hope in Asia. In: Grace G., O’Keefe J. (eds) International Handbook of Catholic Education. International Handbooks of Religion and Education, vol 2. Springer, Dordrecht. https://doi.org/10.1007/978-1- 4020-5776-2_37

Gutiérrez, A.L.V. (2012). Does a Catholic education have lasting effects on adult life? Reflections of alumni from Catholic colleges and universities in the Philippines. International Studies in Catholic Education, 4(1), 16-34

Hadian Nasab, A. and Afshari, L. (2019). Authentic leadership and employee performance: mediating role of organizational commitment. Leadership \& Organization Development Journal, 40(5), 548-560.

Hernando-Malipot, M. (2018, August 20). Free higher education 'killing' private schools slowly - CEAP. Manila Bulletin. Retrieved January 30, 2021, from https://mb.com.ph/2018/08/20/free-higher-education-killing-private-schools-slowly-ceap/

Hlongwane, V. \& Olivier, B. (2017). Authentic leadership influences on organisational commitment in a South African state hospital, Journal of Psychology in Africa, 27(5), 400-404

Luthans, F., Avolio, B. J., \& Avey, J. B. (2007). Psychological Capital Questionnaire. [Measurement Instrument]. Retrieved November 27, 2020, from Mind Garden, Inc. www.mindgarden.com

Luthans, F., Youssef, C. M., \& Avolio, B. J. (2007). Psychological capital: Developing the human competitive edge. Oxford University Press.

Meyer, J.P., \& Allen, N.J. (1991), A three-component conceptualization of organization commitment. Human Resource Management Review, 1(1), 61-89.

Meyer, J. P., Allen, N. J., \& Smith, C. A. (1993). Commitment to organizations and occupations: Extension and test of a three-component conceptualization. Journal of Applied Psychology, 78(4), 538-551.

Montemayor, M.T. (2018, December 28). Free college education in full swing in 2018. Philippine News Agency. Retrieved January 30, 2021, from https://www.pna.gov.ph/articles/1057514

NCEA Talk (2018, August 9). Importance of Catholic schools today. Retrieved May 2, 2021, from https://nceatalk.org/2018/08/importance-of-catholic-schools-today/

Northhouse, P. G. (2012). Leadership: Theory and Practice (6th ed.). California: SAGE Publications.

Peterson, S. J., Luthans, F., Avolio, B. J., Walumbwa, F. O., \& Zhang, Z. (2011). Psychological capital and employee performance: A latent growth modelling approach. Personnel psychology, 64, 427-450. 
Ramos, C. (2020, September 13). Gatchalian seeks quick release of aid to displaced teachers, school workers. Inquirer.net. Retrieved November 24, 2020, from https://newsinfo.inquirer.net/1334892/gatchalian-seeks-fast-smooth-release-of-aid-to-displacedteachers-other personnel

Rego, P., Lopes, M.P., \& Nascimento, J.L. (2016). Authentic Leadership and Organizational Commitment: The Mediating Role of Positive Psychological Capital. Journal of Industrial Engineering and Management, 9(1), 129-151.

Roncesvalles, M. C., \& Gaerlan, A.A. (2020). Authentic Leadership and Teacher Morale: Effects on Organizational Commitment In Higher Education. International Journal of Advanced Research and Publications, 4(3), 85-94.

Shorten A., \& Smith, J. (2017). Mixed methods research: expanding the evidence base. Evidence-Based Nursing, $20,74-75$.

Simons, J. C. \& Buitendach, J. H.(2013). Psychological capital, work engagement and organizational commitment amongst call center employees in South Africa. SA Journal of Industrial Psychology, 39(2), 1- 12.

Sunga, L. (2020). The Role of Authentic Leadership and Authentic Followership to Self-Efficacy, Work Engagement and Organizational Commitment among Nurses. EC Clinical and Medical Case Reports, 3(9), 74-92.

Walumbwa, F. O., Avolio, B. J., Gardner, W. L., Wernsing, T. S., \& Peterson, S. J. (2008). Authentic Leadership: Development and Validation of a Theory-Based Measure. Journal of Management, 34(1), 89-126.

Wong, A., \& Tong, C. (2013). An evaluation of Employee Commitment of Part-Time Faculty (PTF) in Hong Kong's Continuing Professional Development (CPD) Sector. International Journal of Human Resource Studies, 3(4), 4562.

Zeidan, S. (2006). Workers' affective commitment and their willingness to perform discretionary work behavior: The impact of commitment-oriented human resources management practices. Journal of Business Systems, Governance and Ethics, 13-23. 